一一論＼cjkstart文—

（日本化学会誌，1985，（8）, p. 1609～1613）

(C) 1985 The Chemical Society of Japan

\title{
$(\mathbf{B a}, \mathbf{P b})(\mathbf{Z r}, \mathbf{T i}) \mathbf{O}_{3}$ の合成と特性
}

\author{
（1985 年 4 月 5 日 受 理）
}

掛川一幸*・毛利純一・青木宏義

$(\mathrm{Ba}, \mathrm{Pb})(\mathrm{Zr}, \mathrm{Ti}) \mathrm{O}_{3}$ 固溶体（以下 BPZT と略記する）の組成変動を定量する方法を開発し，組成変 動のない固溶体を合成する方法を考案した。

当該固溶体にはバリウムと鉛位置の組成変動とジルコニウム，チタン位置の組成変動が考えられるの でそれらを分離して求めなければならない。 $c$ 軸の長さは $\left(\mathrm{Ba}_{x} \mathrm{~Pb}_{1-x}\right)\left(\mathrm{Zr}_{y} \mathrm{Ti}_{1-y}\right) \mathrm{O}_{3}$ の $x$ のみに依存し て $y$ には依存しない。このことを利用して $00 l$ 回折についての $\beta \cos \theta \sim \sin \theta$ のプロットの勾配から $x$ の 値の変動の幅を見積ることができた。また $(h 0 h)$ 面の面間隔は $y$ のみに依存して $x$ の値には依存しな いので, この面の間隔の変動を求めることにより $y$ の值の変動を求めることができた。

$\mathrm{BaCO}_{3}, \mathrm{PbO}, \mathrm{ZrO}_{2}, \mathrm{TiO}_{2}$ の固体間反応 (乾式法) で合成された $\mathrm{BPZT}$ には Aサイト， Bサイト ともに組成変動が存在した。一方, ベリウムー鉛の共沈体とジルコニウムーチタンの共沈体との固体間反 応 (湿式一乾式組み合わせ法) により組成変動のないBPZT が得られた。乾式法と湿式一乾式法の反応 過程を高温X線により追跡した結果, 湿式一乾式組み合わせ法は反応性が良好であった。誘電率の Curie 点でのピークは湿式一乾式組み合わせ法によるものの方が鋭く大きかった。一方のサイトの成分のみを 共沈体を用いて，残りは固体間反応によって BPZT を合成し，その組成変動についても検討した。そ の結果, これらの試料にもわずかながら組成変動が存在した。

\section{1 緒言}

酸化チタン $(\mathrm{N})$ バリウム (チタン酸バリウム $\mathrm{BaTiO}_{3}$ ) や酸化 チタン (N)鉛(II)（チタン酸鉛 $\mathrm{PbTiO}_{3}$ ) などペロブスキー石型 㩐造を有する化合物の多くが強誘電性, 反強誘電性を示し, 有用 な電気的特性を有する。これら単一の化合物に異種イオンを添加 して ${ }^{1221}$, 電気的, 物理的特性を改良することが一般に行なわれて

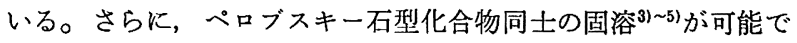
あって, 特性の多様化を容易にしている。 $\mathrm{BaTiO}_{3}-\mathrm{SrTiO}_{3}{ }^{6}{ }^{6}, \mathrm{Ba}$ ・ $\mathrm{TiO}_{3}-\mathrm{BaTiO}_{3}{ }^{7}$ などの固溶は Curie 点を移聠させるのにしばし ば行なわれる。 $\mathrm{PbTiO}_{3}-\mathrm{PbZrO}_{3}$ 系固溶体（PZT）はモルホトロ ピック相境界をむち，その近傍で压電係数が最大になる8)。PZT は，その優れた特性のために圧電材料の基本材料としてもっとも 多く用いられている。PZT $\mathrm{O}_{3}{ }^{10)}, \mathrm{BaTiO}_{3}$ などを固溶させた三成分系, 四成分系固溶体 ${ }^{11}$ は

千葉大学工学部工業化学科, 290 千葉市弥生町

1) R.Gerson, J. Appl. Phys., 31, 188(1960).

2) R. Roy, J. Am. Ceram. Soc., 37, 581(1954).

3) T. Ikeda, J. Phys. Jpn., 14, 1286(1959).

4) B. Jaffe, R. S. Roth, S. Marzullo, J. Res. Nat. Bur. Stand., 55, 239(1955).

5) T. Ikeda, J. Phys. Soc. Jpn., 14, 168(1959).

6) E. Hegenbarth, Phys. Status Solidi, 9, 191(1965).

7) K. Suzuki, J. Phys. Soc. Jpn., 6, 340(1951).

8) B. Jaffe, R.S. Roth, S. Marzullo, J. Appl. Phys., 25, 809(1954).

9) N. N. Krainik, A. I. Agranovskaya, Fiz. Tverd. Tela, 2, 70(1960).
圧電定数，機械的定数，Curie 点などの幅広い組み合わせが可能 である。

一般にペロブスキー石型化合物の固溶体には組成変動が発生し やすく 12) 14), 強誘電相 $\rightleftarrows$ 常誘電相転移が散僈になったり ${ }^{15)}$, モルホトロピック相境界での優れた特性が十分引きだなかった りする ${ }^{16)}$ 。これまでに，Aサイト固換型固溶体である $(\mathrm{Ba}, \mathrm{Pb})$. $\mathrm{TiO}_{3}{ }^{17)}$ と $\mathrm{B}+イ ト$ 置換型固溶体である $\mathrm{Pb}(\mathrm{Zr}, \mathrm{Ti}) \mathrm{O}_{3}{ }^{12) 13)}$ の組成 変動を定量する方法が, 著者らにより考案され, 固体間反応によ り合成されたこれら固溶体には大きな組成変動のあることが示さ れてきている。

湿式合成は組成変動のない固溶体を得るのに有効な方法である と考えられるが，静成イオンの種類が多くなるにしたがって困難

10) G. A.Smolenskii, A.I. Agranovskaya, Fiz. Tverd. Tela, 1, 1562 (1959).

11）渡辺秀夫，エレクトロニクセラミクス，2，63(1971).

12）掛川一幸, 渡辺 橴, 毛利純一, 山村 博, 白崎信一, 日 化, 1975, 413.

13) K. Kakegawa, J. Mohri, S. Shirasaki, K. Takahashi, J. Am. Ceram. Soc., 65, 515(1982).

14) K. Kakegawa, J. Mohri, H. Ishiguro, K. Takahashi, Chem. Lett., 1982, 1655.

15）掛川一幸, 毛利純一, 白崎信一，山村 博, 高橋絃一郎, 日化, 1974, 10.

16) K. Kakegawa, J. Mohri, K. Takahashi, H. Yamamura, S. Shirasaki, Solid State Commun., 24, 769 (1977).

17）掛川一幸, 毛利純一, 千泟俊一, 白崎信一, 高橋数一郎, 日化, 1985,9 . 
さが増す。著者らは、これまでに同一サイトの構成陽イオンのみ を湿式で得て，他のサイトの成分と固体間反応させることで組成 変動のない $(\mathrm{Ba}, \mathrm{Pb}) \mathrm{TiO}_{3}{ }^{14) 17}, \mathrm{~Pb}(\mathrm{Zr}, \mathrm{Ti}) \mathrm{O}_{3}{ }^{18) 197}$ 固溶体を合成 することに成功している。本報告では $\mathrm{A}$ サイト， Bサイトいずれ のサイトも固換固溶している $(\mathrm{Ba}, \mathrm{Pb})(\mathrm{Zr}, \mathrm{Ti}) \mathrm{O}_{3}$ (以下 $\mathrm{BPZT}$ と略記する）の組成变動を定量する方法を示し, さらにA+イト 構成陽イオンの共沈体と Bサイト構成陽イオンの共沈体との固体 間反応により BPZT を合成し，その組成変動を検討した。

\section{2 実 験 方 法}

\section{1 試 料}

BPZT は一般的な乾式法と, 今回初めて試みた湿式一乾式組み 合わせ法により合成した。乾式法はつぎのようにして行なった。

$\mathrm{BaCO}_{3}$ (和光純薬製, 特級), $\mathrm{PbO}$ (純正化学製, 特級), $\mathrm{ZrO}_{2}$ (三津和化学薬品製, $99.9 \%$ ), $\mathrm{TiO}_{2}$ (純正化学製, 特級) を所定 の割合で調合し，めのうの乳鉢を用いて十分に混合した。この混 合物を約 $75 \mathrm{MPa}$ の圧力で直径約 $13 \mathrm{~mm}$, 厚さ約 $2 \mathrm{~mm}$ のペレ ット状に成形し，白金パイプ中に封入し $1100^{\circ} \mathrm{C} て ゙ 2$ 時間焼成し た。このさい, 試料から発生する $\mathrm{CO}_{2}$ による白金パイプの破裂 を防ぐため溶封部分の一部にわずかなピンホールを残した。以下 この方法を $[\mathrm{B}+\mathrm{P}+\mathrm{Z}+\mathrm{T}]$ と省略する。湿式一乾式組み合わせ法 の工程を図 1 に示す。酢酸鉛(II)三水和物 $\left(\mathrm{Pb}\left(\mathrm{CH}_{3} \mathrm{CO}_{2}\right)_{2} \cdot 3\right.$ $\mathrm{H}_{2} \mathrm{O}$, 和光純薬製, 特級) の約 $0.5 \mathrm{~mol} / l$ の水溶夜を調製 し, EDTA によりその濃度を求めた。また，酢酸バリウム(Ba・ $\left(\mathrm{CH}_{3} \mathrm{CO}_{2}\right)_{2}$, 関東化学製, 特級) の約 $1.5 \mathrm{~mol} / l$ の水溶液を調製 し, 重量法により, その濃度を求めた。科量形は炭酸バリウムと した。酢酸鉛(II)水溶液と酢酸バリウム水溶液を所定の割合で混 合し, 炭酸アンモニウム水溶液（約 $6 \mathrm{~mol} / l$ ) に滴下し沈殷を得 た。これを汇過，洗浄，乾燥した。この沈段物は炭酸バリウムと 炭酸鉛(II)の固溶体であった（以下 BP と略記する)。これとは 別に二塩化酸化ジルュニウム $(\mathrm{N})$ 八水和物 $\left(\mathrm{ZrCl}_{2} \mathrm{O} \cdot 8 \mathrm{H}_{2} \mathrm{O}\right.$, 半井 化学製, 特級) 水溶夜 (約 $1.5 \mathrm{~mol} / l$ ) と塩化チタン $(\mathrm{N})$ (関東化 学製, 特級) 水溶液（約 $2.5 \mathrm{~mol} / l$ ) を調製し, 重量法でその濃度 を求めたのち, 所定の割合で混合し, 約 $3 \mathrm{~mol} / l$ のアンモ=ア水 に滴下して沈殿を得た。この沈殿を汇過, 洗浄, 乾燥後, $900^{\circ} \mathrm{C}$ で 1 時間焼成することにより酸化物の形にした。この粉末（以下

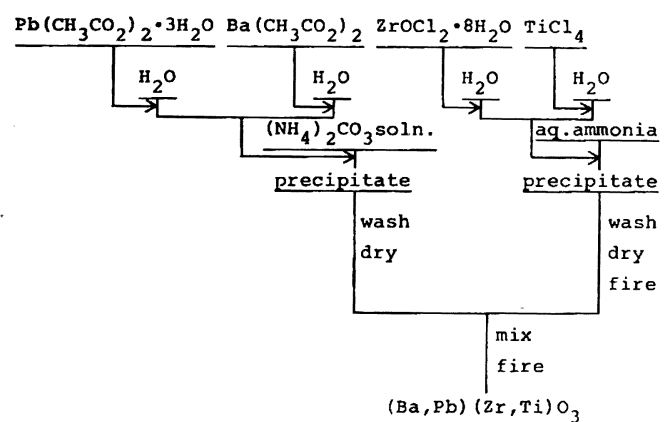

Fig. 1 Process for preparing BPZT by wet-dry combination method

18）挂川一幸, 毛利純一, 高橋紘一郎, 山村 博, 白崎信一, 日化, 1976, 717 .

19) K. Kakegawa, J. Mohri, S. Shirasaki, K. Takahashi, J. Am. Ceram. Soc., 67, C-2(1984).
$\mathrm{ZT}$ と略記する）は $\mathrm{ZrTiO}_{4}$ と $\mathrm{TiO}_{2}$ (ルチル) の混合物であっ た。ZT と前に述べた BP とを 1:1のモル比になるよう調合し， めのうの乳鉢で十分混合したのち，乹式の場合と同様の焼成を行 なって BPZT を得た。以下この方法を湿式一乾式組み合わせ法と 呼び,この合成法を $[\mathrm{BP}+\mathrm{ZT}]$ と標記する。また，一方のサイト の成分のみを湿式で得て残りの成分と固体間反応させた試料も合 成した。 $\mathrm{BaCO}_{3}, \mathrm{PbO}$ および $\mathrm{ZT}$ との固体間反応を $[\mathrm{B}+\mathrm{P}+$ $\mathrm{ZT}], \mathrm{ZrO}_{2}, \mathrm{TiO}_{2}$ および $\mathrm{BP}$ との固体間反応を $[\mathrm{BP}+\mathrm{Z}+\mathrm{T}]$ と略記する。これら試料についても $[\mathrm{B}+\mathrm{P}+\mathrm{Z}+\mathrm{T}],[\mathrm{BP}+\mathrm{ZT}]$ と同じ条件で焼成した。

\section{$2.2 \mathrm{X}$ 線回折}

常温粉末 X線測定は理学電機製 D-6 C, SG-7 型を用いた。使 用 $\mathrm{X}$ 線は $\mathrm{Cu} K_{\alpha}$ 線とし, 発散スリット $1^{\circ}$, ニッケルフィルタ 一, 受光スリット $0.15 \mathrm{~mm}$, 散乱スリット $1^{\circ}$ の光学系を用い た。格子定数は粉末ヶイ素 (高純度化学研究所製, 99.99\%) を内 部棒準として試料の 002, 200 回折から求めた。また, 测定され るピークは銅の $K_{\alpha_{1}}$ 線と $K_{\alpha_{2}}$ 線の重なったものであるから, 回 折ピークの形を最小二乗法を用いて次式

$$
I(2 \theta)=\frac{a}{1+b(2 \theta-c)^{2}}+\frac{0.5 a}{1+b(2 \theta-c-\Delta)^{2}}
$$

に一致させ単一波長に対する試料の半值幅を求めた。同様に粉末 ケイ素との石英の単一波長に対するピークの広がりを求め, これ を回折装置の光学系による広がりとみなした。試料のピーク位置 での光学系の幅を内挿により求め試料の幅から差し引き, 試料自 体に起因する幅 $(\beta)$ とした。

原料混合物の反応過程を高温 X線回折装置（日本電子製）によ り追跡した。2 $\theta$ が $25^{\circ}$ から $33.5^{\circ}$ の間を每分 $2^{\circ}$ の速度で往復走 査させながら毎分 $5^{\circ} \mathrm{C}$ で昇温させピークの変化を調べた。

\section{3 電気測定}

焼結体の両面に銀ペースト（住友金属鉱山製，3-871 C) を塗布 し, $500^{\circ} \mathrm{C} て ゙ 10$ 分間焼き付けた。この試料を電気炬にセット し，その電気容量を LF インピーダンスアナライザー（YHP $4192 \mathrm{~A}$ 型) で測定して誘電率を求めた。

\section{3 結果および考察}

図 2 に $\left(\mathrm{Ba}_{x} \mathrm{~Pb}_{1-x}\right)\left(\mathrm{Zr}_{y} \mathrm{Ti}_{1-y}\right) \mathrm{O}_{3}$ の組成と格子定数との関俰 を示す。この組成範囲では BPZT は正方晶である。 $a$ 軸の長さは $x$ の值にも $y$ の值にも依存するが $c$ 軸の長さは注ぼ $x$ の值のみ によって決まっている。ここで $x$ の値に変動があるとすると $c$ 軸 の長さの変動がもたらされる。 $c$ 軸の長さは，yの值には依存し ないので, $y$ の值の変動の影響は受けない。したがって $c$ 軸の長 さの変動を知ることができれば $x$ の值の変動を見積ることが可能 となる。 $c$ 軸の長さの変動は, $c$ 軸の長さのみによって面間隔が 定まる $(00 l)$ 面についての $\beta \cos \theta \sim \sin \theta$ のプロットから求める ことができる。すなわち $(00 l)$ 面についての $\beta \cos \theta \sim \sin \theta$ のプ ロットの勾配は $\left(\mathrm{Ba}_{x} \mathrm{~Pb}_{1-x}\right)\left(\mathrm{Zr}_{y} \mathrm{Ti}_{1-y}\right) \mathrm{O}_{3}$ の $x$ の值の変動のパ ラメーターとすることができる。一方， $a$ 軸の長さは $x$ の值にも $y$ の值にも依存するので組成変動のパラメーターとすることはで きない。ところで, $x$ の值の增加につれて $c$ 軸の長さは娍少し, $a$ 軸の長さは增大している。したがって, 長さの増大と減少が相 殺されて $x$ の值に依存しない面があるはずである。種々の面につ いて $x$ の值に対する面間隔の变化率を調べた結果 $(h 0 h)$ 面は $x$ 


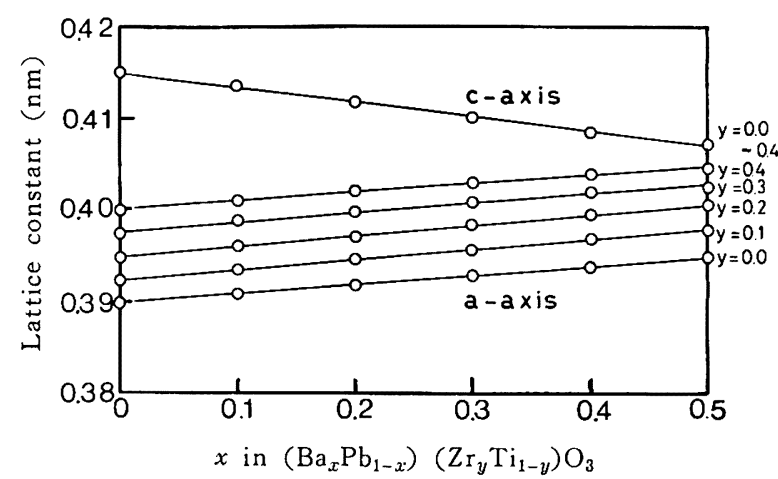

Fig. 2 Relation between lattice constants and compositional fluctuation

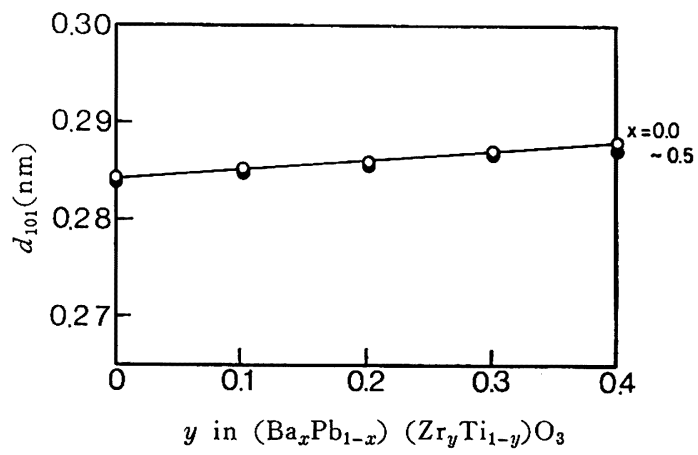

Fig. 3 Relation between $d_{101}$ and compositional fluctuation

の值にはほとんど依存しないことがわかった。四3に $(h 0 h)$ 面 の代表面である (101) 面の面間隔 $\left(d_{101}\right)$ と $y$ との関係を示す。 $d_{101}$ は $y$ の值が大きくなるにしたがって大きくなるが， $x$ の值に は注とんど依存しない（それぞれのyに対して白丸印から黒丸印 の間の笘罒に収まっている)。したがってこの面の間隔の変動を 調べることにより， $x$ の変動の影響を受けずに $y$ の変動を求める ことができる。この面の間隔の变動は $h 0 h$ 回折についての $\beta$ $\cos \theta$ と $\sin \theta$ との関係のプロットの勾配から求めることができ る。すなわち $h 0 h$ 回折についての $\beta \cos \theta \sim \sin \theta$ のプロットの 勾配は $y$ の值の変動のパラメーターとして用いることができる。

図 4 に BPZT の $\beta \cos \theta \sim \sin \theta$ のプロットを示す。乾式による ものでは, Bサイトの変動を示す $h 0 h$ 回折（黒丸）についても， $\mathrm{A}$ サイトの变動を示す $00 l$ 回折（白丸）についても勾配があり， いずれのサイトにも組成変動のあることがわかる。この試料の $(00 l)$ 面の面間隔の变動 $(\Delta d / d)_{00 l}$ は, プロットの颛きから $5.91 \times 10^{-3}$ と見積もられる。面間隔の変動幅 $\Delta d$ は $\Delta d / d$ の値 に $d=0.41 \mathrm{~nm}$ をかけて $2.42 \mathrm{~nm}$ となる。図 3 を用いて $\Delta d か ゙$ この値になるときの組成の幅 $\Delta x$ を求めると 0.16 となる。した がって $x$ の組成方向の変動の幅は $0.22<x<0.38$ となる。同様に して $h 0 h$ 回折についての傾きから $(\Delta d / d)_{h 0 h}=13.17 \times 10^{-3}$ で あり図 2 を用いて組成の変動幅に換算すると $0.11<y<0.49$ と なり，いずれの組成方向にも变動が大きいことがわかる。これに 対して湿式一乾式組み合わせ法 $[\mathrm{BP}+Z \mathrm{ZT}]$ によるものでは $00 l$ 回 折 (白四角) についても $h 0 h$ 回折（黒四角）についても勾配が

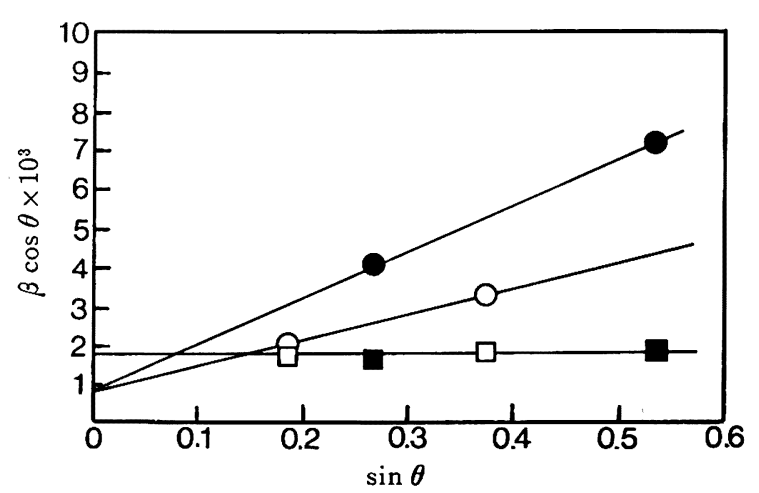

Fig. 4 Plots of $\beta \cos \theta$ vs. $\sin \theta$ for $B P Z T$ fired at $1100^{\circ} \mathrm{C}$ for $1 \mathrm{~h}$

$\mathrm{O}:$ For $00 l$ diffraction of $\mathrm{BPZT}[\mathrm{B}+\mathrm{P}+Z+\mathrm{T}]$

: For $h 0 h$ diffraction of BPZT $[\mathrm{B}+\mathrm{P}+Z+\mathrm{T}]$

$\square$ : For $00 l$ diffraction of $\mathrm{BPZT}[\mathrm{BP}+Z \mathrm{ZT}]$

- For $h 0 h$ diffraction of $\mathrm{BPZT}[\mathrm{BP}+Z \mathrm{~T}]$

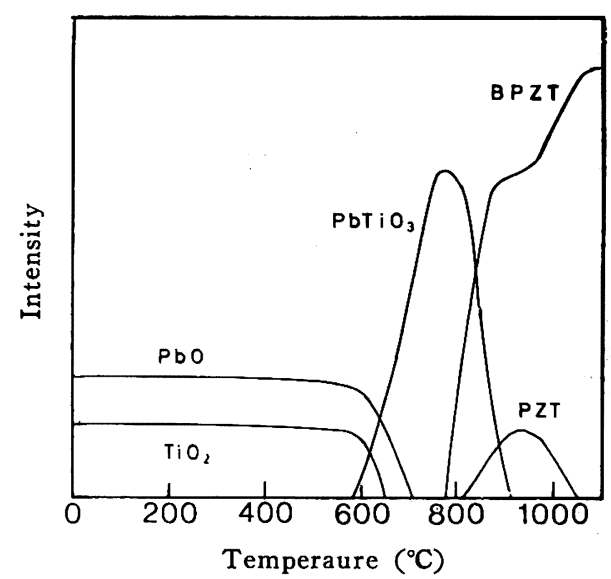

Fig. 5 Reaction products of $\mathrm{BaCO}_{3}, \mathrm{PbO}, \mathrm{ZrO}_{2}$ and $\mathrm{TiO}_{2}$ mixture with a function of temperature determined by high temperature $\mathrm{X}$-ray diffractometry $(\mathrm{Ba}: \mathrm{Pb}: \mathrm{Zr}: \mathrm{Ti}=0.3: 0.7: 0.3: 0.7)$

なく，Aサイトの共沈体と Bサイトの共沈体との固体間反応が組 成変動解消に有効なことがわかる。

乾式と湿式一乾式組み合わせ法の反応過程を調べるために高温 $\mathrm{X}$ 線回折装置により每分 $5^{\circ} \mathrm{C}$ で昇温させピークの高さの変化を 追跡した。図 5 は乾式 $[\mathrm{B}+\mathrm{P}+\mathrm{Z}+\mathrm{T}]$ Kついての反応過程であ る。 $600^{\circ} \mathrm{C}$ 付近から $\mathrm{PbO}, \mathrm{TiO}_{2}$ が減少し, 中間生成物として $\mathrm{PbTiO}_{3}$ が現われる。さらに加熱すると $800^{\circ} \mathrm{C}$ 付近で BPZT が 生成し始める。同時に, この温度付近から PZT が現われる。最 終的には $1050^{\circ} \mathrm{C}$ 付近で BPZT の単一相となった。[BP+ZT $]$ の 場合, この反応よりやや複雑であった。図 6 に湿式一乾式組み 合わせ法についての高温X線回折の結果を示す。原料としては $(\mathrm{Ba}, \mathrm{Pb}) \mathrm{CO}_{3}, \quad \mathrm{ZrTiO}_{4}$ および $\mathrm{TiO}_{2}$ が存在する。 $400^{\circ} \mathrm{C}$ 付近で $(\mathrm{Ba}, \mathrm{Pb}) \mathrm{CO}_{3}$ は分解して $\mathrm{PbO}(\mathrm{red})$ が生じる。 $\mathrm{Pb}_{3} \mathrm{O}_{4}$ は $500^{\circ} \mathrm{C}$ 付近で安定な物質であって $\mathrm{PbO}(\mathrm{red})$ の一部は $450^{\circ} \mathrm{C}$ 付近から $\mathrm{Pb}_{3} \mathrm{O}_{4}$ に変わるが, $600^{\circ} \mathrm{C}$ 付近でふたたび $\mathrm{PbO}$ に戻る。さらに, $\mathrm{PbO}$ (yellow), $\mathrm{BaPbO}_{3}, \mathrm{PbTiO}_{3}$ が中間生成物として現われ, 最 終的には $1000^{\circ} \mathrm{C}$ 付近で BPZT の単一相になる。また BPZT の 


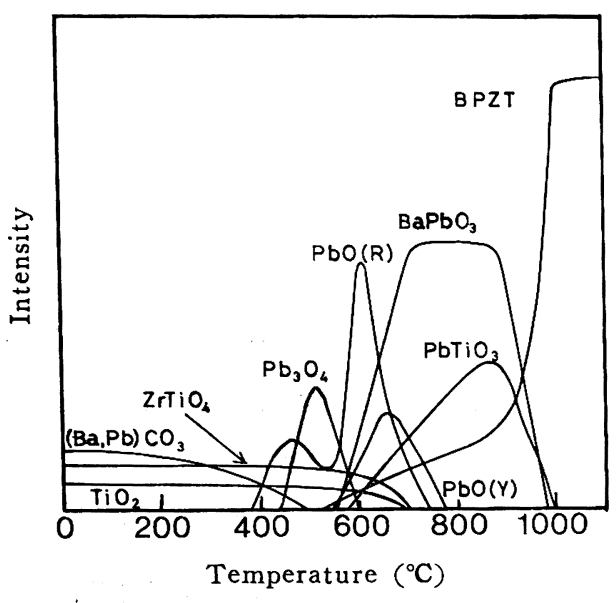

Fig. 6 Reaction products of BP and ZT mixture with a function of temperature determined by high temperature X-ray diffractometry

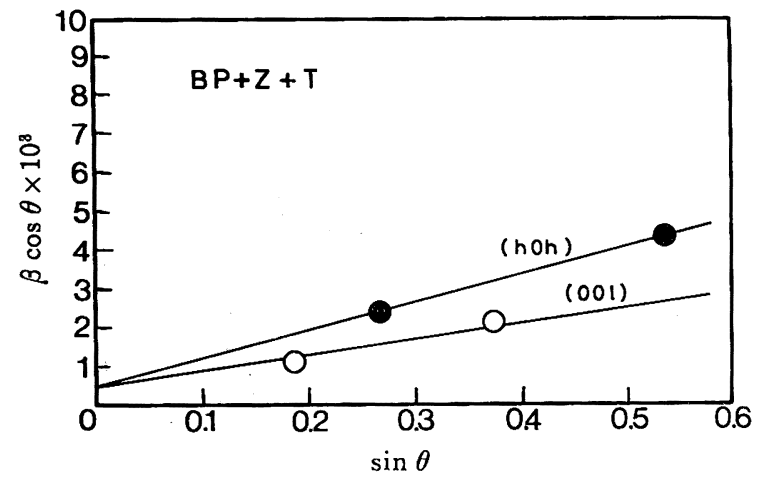

Fig. 7 Plots of $\beta \cos \theta$ vs. $\sin \theta$ for BPZT prepared by a solid state reaction among $\mathrm{BP}, \mathrm{ZrO}_{2}$ and $\mathrm{TiO}_{2}$

生成し始ある温度も500 ${ }^{\circ} \mathrm{C}$ 付近とかなり低温になっている。乾式 法と湿式一乾式組み合わせ法について反応性を比較すると, 湿式一 乾式組み合わせ法の方が良好であることがわかった。

すでに述べたように同一のサイトに入る成分が均一に混合され ていれば，合成された BPZT には組成変動はなくなる。ここで, 一方のサイトの成分のみ共沈体を用いた場合, そのサイトの組成 変動が解消されるかどうか興味がもたれる。Aサイトの成分のみ を共沈体を用いて合成した BPZT ([BP $+Z+T])$ および Bサイ トの成分のみを共沈体を用いたもの $([\mathrm{B}+\mathrm{P}+\mathrm{ZT}])$ についても その組成変動を検討した。図 7 は $[\mathrm{BP}+Z+\mathrm{T}]$ についての $\beta$

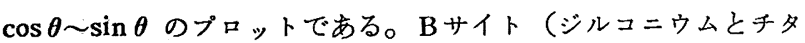
ソ）の組成変動を示す $h 0 h$ 回折の勾配は $[\mathrm{B}+\mathrm{P}+Z+\mathrm{T}]$ の場合 より小さくはなっているが勾配がある。Aサイトの組成変動を示 す $00 l$ 回折についてのプロットにも小さいながら勾配が現われ ている。このことは当該サイトの原料が均一であっても他のサイ トが不均一であれば組成変動が発生することを意味している。一 方，Bサイトの原料のみを共沈体を用いた $[\mathrm{B}+\mathrm{P}+\mathrm{ZT}]$ につい ての結果を図 8 に示す。この試料では $[\mathrm{BP}+\mathrm{Z}+\mathrm{T}]$ の場合とは 逆に $00 l$ 回折についての勾配が大きなっている。00 $l$ 回折につ

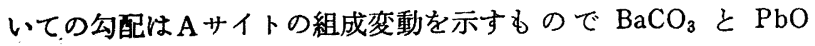
が乾式混合によっているのであるから順当な結果である。 $h 0 h$

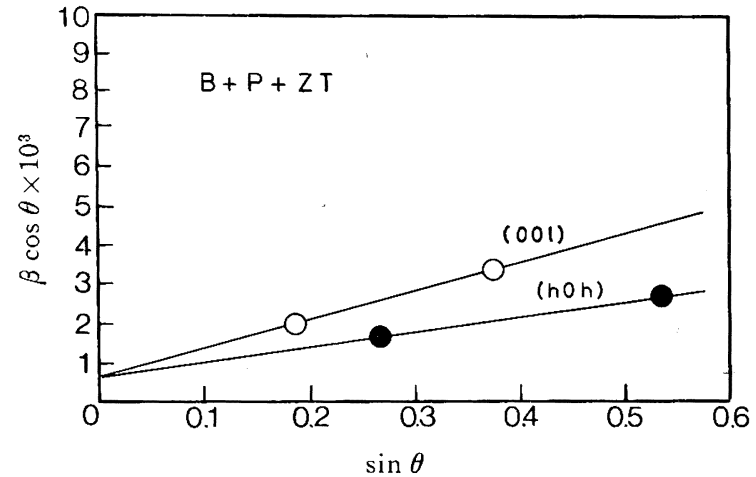

Fig. 8 Plots of $\beta \cos \theta$ vs. $\sin \theta$ for BPZT prepared by a solid state reaction among $\mathrm{BaCO}_{3}, \mathrm{PbO}$ and $\mathrm{ZT}$

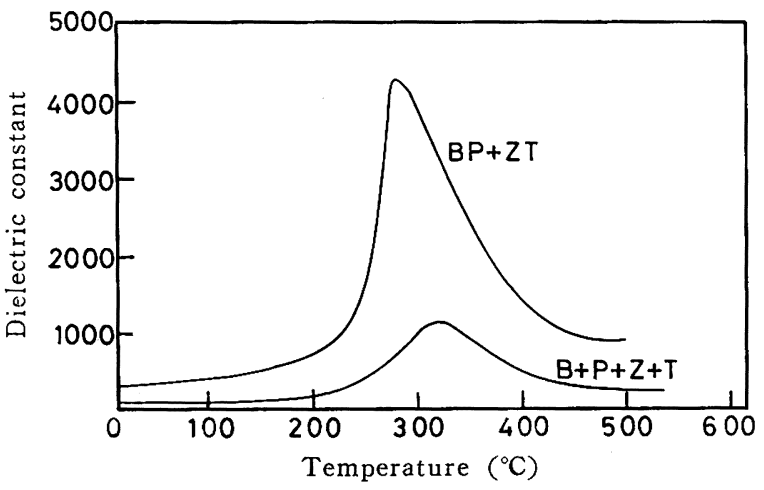

Fig. 9 Dielectric constant of synthesized BPZT as a function of temperature

回折についてのプロットの結果からBサイトにも多少の組成変動 のあることがわかる。原料としてはZT を用いたのであるから B サイトは均一と予想されるが， $[\mathrm{BP}+Z+\mathrm{T}]$ の場合と同様に，他 のサイトの不均一の影響を受けたものと考えられる。これらの結 果を総合すると，Aサイト，Bサイトともに㯰換固溶している BPZT を合成するにはAサイト成分の共沈体と Bサイト成分の共 沈体とを固体間反応させる方法がもっとも好ましいと考えること ができる。

BPZT は常温で強誘電体で, Curie 点で常誘電相に転移する。 この転移点付近で誘電率のピークが現われる。図 9 に $[\mathrm{B}+\mathrm{P}+\mathrm{Z}$ $+\mathrm{T}],[\mathrm{BP}+\mathrm{ZT}]$ によって合成された BPZT の誘電率の温度特 性を示す。合成条件は，いずれも $1100^{\circ} \mathrm{C} て ゙ 1$ 時間焼結したもの である。この固溶体の焼成条件としては比較的低い方であるが [BP+ZT $]$ Kよるものでは誘電率が高く，鋭いピークを示してい る。これに対して $[\mathrm{B}+\mathrm{P}+\mathrm{Z}+\mathrm{T}]$ では, 誘電率がかなり低く，そ の幅も広くなっている。誘電率の大きさについては焼結性の差が おもな原因と考えられる。また, 組成変動が存在すると, 試料中 に種々の Curie 点をもつ粒子が混在することになり, その総和と して幅広くなることが予想され，実際そのような結果が得られ た。鋭いピークを示す $[\mathrm{BP}+Z \mathrm{ZT}]$ の温度特性を, 組成変動に対応 させて Curie 点をずらし単純な総和を計算すると,ピークが幅広 くなると同時に, ピークの位監は高温側に移動することがわかっ た。ピークの位置の多少のずれはこのことに関係しているものと 考えられる。亦た, $[\mathrm{B}+\mathrm{P}+\mathrm{Z}+\mathrm{T}]$ ではX線にかからない程度の 
$\mathrm{PZT}$ が中間生成物（図 5 参照）として混在していることも考えら れ，それがピークの位置のずれや幅広いピークの原因となってい るのかもしれない。いずれにせよ, 誘電特性の面からも $[\mathrm{BP}+$ ZT $]$ による BPZT は単なる乾式法 $[\mathrm{B}+\mathrm{P}+Z+\mathrm{T}]$ にくらべて筞 れていることもわかった。

\section{4 結論}

本研究によりつぎの結論を得た。

(1) $00 l$ 回折についての $\beta \cos \theta \sim \sin \theta$ のプロットの勾配から $\mathrm{A}$ サイトの組成変動を見積ることができ, $h 0 h$ 回折についての
プロットの勾配から Bサイトの組成変動を見積ることができた。

(2) $\mathrm{A}$ サイト成分の共沈体と B+イト成分の共沈体との固体間

反応（湿式一葫式組み合わせ法）に上り組成变動のない $(\mathrm{Ba}, \mathrm{Pb})$

$(\mathrm{Zr}, \mathrm{Ti}) \mathrm{O}_{3}$ 固溶体を得ることができた。

(3) 乾式法にくらべて湿式一乾式組み合わせ法の方が反応性が 良好で誘電率も高く, Curie 点でのピークの鋭い試料が得られ た。

(4) 一方のサイトの構成成分のみ湿式で得て残りは固体間反応 させた試料ではいずれのサイトにも組成変動が生じた。 本研究は文部省科学研然費の補助を受けて行なった。

\section{Synthesis of $(\mathrm{Ba}, \mathrm{Pb})(\mathrm{Zr}, \mathrm{Ti}) \mathrm{O}_{3}$ and Their Properties}

Kazuyuki Kakegawa*, Jun-ichi Mohri and Hiroyoshi Aoki

Faculty of Engineering, Chiba University; Yayoi-Cho, Chiba-shi 260 Japan

A method to determine the compositional fluctuations of $(\mathrm{Ba}, \mathrm{Pb})(\mathrm{Zr}, \mathrm{Ti}) \mathrm{O}_{3}(\mathrm{BPZT})$ solid solution was developed, and a new technique to synthesize the BPZT solid solution having no compositional fluctuations was designed.

Solid solutions of BPZT has two kinds of compositional fluctuations originating from Asite and B-site. Both compositional fluctuations were determined discretely, as follows. The fluctuation due to the variation of $x$ was estimated through the fluctuation of the $c$-axis length, which was determined from a slope of the relation between $\beta \cos \theta$ and $\sin \theta$ of $00 l$ diffractions, because the $c$-axis length does not depend on $y$, but on $x$ in $\left(\mathrm{Ba}_{x} \mathrm{~Pb}_{1-x}\right)\left(\mathrm{Zr}_{y} \mathrm{Ti}_{1-y}\right) \mathrm{O}_{8}$. On the other hand, the fluctuation due to the variation of $y$ was determined by measuring the fluctuation of the $(h 0 h)$ interplanar spacing, which does not depend on $x$, but on $y$.

The BPZT solid solution, prepared by a solid state reaction among $\mathrm{BaCO}_{3}, \mathrm{PbO}, \mathrm{ZrO}$ and $\mathrm{TiO}_{2}$ by dry process, had large compositional fluctuations due to both A-site and $\mathrm{B}$-site. On the contrary, the BPZT solid solution, prepared by a solid-solid reaction between a coprecipitated barium and lead carbonates (BP) and that of zirconium and titanium (ZT) by wet-dry combination process, had no compositional fluctuations. Results of a high temperature X-ray diffractometry revealed that the reactivity of BPZT synthesized by the wet-dry combination process was good. The dielectric constant of BPZT prepared by the wet-dry combination process was high, and its diffraction peak at Curie point was very sharp.

The combinations of $\mathrm{BP}+\mathrm{ZrO}_{2}+\mathrm{TiO}_{2}, \mathrm{BaCO}_{3}+\mathrm{PbO}+\mathrm{ZT}$ were also studied. Both of them had a small compositonal fluctuations. 